\title{
Consumers' Attitudes towards Organic Products and Sustainable Development: A Case Study of Romania
}

\author{
Camelia F. Oroian ${ }^{1}$, Calin O. Safirescu ${ }^{2, *}$, Rezhen Harun ${ }^{3}$, Gabriela O. Chiciudean ${ }^{1}$, \\ Felix H. Arion ${ }^{1}$ (D), Iulia C. Muresan ${ }^{1}$ (i) and Bianca M. Bordeanu ${ }^{2}$ \\ 1 Department of Economic Sciences, Faculty of Horticulture, University of Agricultural Sciences and \\ Veterinary Medicine Cluj-Napoca, 3-5 Manastur Street, 400372 Cluj-Napoca, Romania; \\ camelia.oroian@usamvcluj.ro (C.F.O.); gabriela.chiciudean@usamvcluj.ro (G.O.C.); \\ felixarion@usamvcluj.ro (F.H.A.); iulia.muresan@usamvcluj.ro (I.C.M.) \\ 2 Department of Environmental and Plant Protection, Faculty of Agriculture, University of Agricultural \\ Sciences and Veterinary Medicine, Cluj-Napoca, 3-5 Manastur Street, 400372 Cluj-Napoca, Romania; \\ bianca.bordeanu@usamvcluj.ro \\ 3 Department of Agribusiness and Rural Development, College of Agricultural Sciences, University of \\ Sulaimani, Kurdistan Regional Government-Iraq, Sulaimani-Bakrajo-Awal 5100, Iraq; \\ rezhen.rashid@univsul.edu.iq \\ * Correspondence: calin.safirescu@usamvcluj.ro; Tel.: +40-745-584-923
}

Received: 27 July 2017; Accepted: 29 August 2017; Published: 6 September 2017

\begin{abstract}
Organic food consumption has increased during the last years as a consequence of its direct impact on consumer health, life style, and social convenience as well as on the environment and sustainable development. Compared to the European level, the consumption of organic food products is quite low in Romania. This paper investigates the perception and attitudes of the organic food consumers from the North-West Development Region of Romania. Consumers' perception towards organic food products was measured using 30 items. The data were collected from 568 respondents and analyzed using descriptive and inferential statistics. A factor-cluster approach was used to identify consumer groups. The findings indicated that health concerns, sensory appeal, sustainable consumption and weight concerns are the main reasons for consuming organic food products. Three main groups of organic food consumers were identified: "gourmand", "environmentally concerned" and "health concerned".
\end{abstract}

Keywords: food value chain; organic food products; consumer behavior

\section{Introduction}

Organic farming is a viable alternative to conventional agriculture and contributes to sustainable development in terms of food safety and quality, environment and animal welfare [1]. In the European Union, the organic surfaces cultivated have increased from 5.0 million in 2002 to 11.0 million hectares in 2015 [2].

There is general consensus that the demand for organic food substantially has increased in the last two decades, transforming a niche-industry into a well-developed market $[3,4]$. The reason for this phenomenon lays firstly within the changes in the consumer perception on food, which, according to scholars [5], is no longer just a means to satisfy hunger, but has gained multiple dimensions due to consumer concerns on health issues, environmental safety and animal welfare. To meet the demand for organic products, the main actors on the organic market must be aware of consumer perceptions regarding these products [6]. 


\section{Organic Market in Romania}

In Romania, the organic food market is also increasing and the statistical data from the Ministry of Agriculture and Rural Development confirm it: the number of certified organic farmers increased four times from 2010 onto 2015, while the cultivated organic surfaces doubled during the same period [7].

Romanian studies regarding the organic food market follow two main directions: (1) analysis of the organic agriculture sector to find proper development methods [8-10]; and (2) analysis of consumers' behavior towards organic food [11,12]. Romanian consumption of organic food is relatively low $(1 \%)$ compared to the European level (3-5\%). It is considered that the Romanian organic food sector has an insignificant share within the agro-food sector, but great potential [8].

Thus, Draghici et al. [12] concluded that, based on the results of the research conducted in Bucharest, the capital city of Romania, the dynamics of the organic food market are moderate and mainly influenced by economic factors, including the low income per capita as the most relevant [12]. The organic food buyers in Bucharest were divided into three main clusters, the occasional buyers held the highest percentage ( $42.2 \%)$, followed by loyal buyers (30\%) and non-buyers (27.3\%).

Furthermore, Balasescu [9] concluded that Romanian consumers are preoccupied with healthy food, but also with sustainable agricultural development and environmental safety, which creates a favorable context for organic agriculture to develop and to face the increasing demand. Scholars underlined that the main reasons for purchasing organic food in Romania are health and environmental concerns [13-15].

It is known that more than $30 \%$ of greenhouse gas (GHG) emissions are generated by all consumer purchases from the food and drinks sector [16]. This is a consequence of the actual organizational value chain and its unsustainable development trend, as the food and food-related waste creates huge environmental, economic and social problems [17]. This has a direct influence on each of the three pillars (economic, social and environmental), as the economic dimension seems to prevail in modern society over the other two, while humanity struggles for a more sophisticated diet. Direct consequences may include major social clashes on the grounds of food availability and critical shortages of primary resources, in terms of land availability and productivity, clean water accessibility and biodiversity conservation. At the same time, population pressure increases, as well as its concentration in urban agglomerated areas and its continuous adaptation to a richer and more diversified diet. This development generates additional medium-term concerns. In this context, environmental and social pillars of sustainable development cannot be neglected.

The aim of the present study was to identify the differences between consumer groups of organic food products from the North-West Development Region of Romania regarding their perceptions and attitudes towards these food products. In the same time producers and sellers will have a profile of their consumers, which will help them adapt the products to their needs. Finally, the organic agricultural and food policy could benefit from a more appropriate approach of the concept along the lines of an urban-rural integrated strategy to promote a faster transfer of food research and innovations [18].

\section{Literature Review}

Previous studies have provided a general analysis of the major motivations that stand behind the organic food buying behavior of consumers. In relation to environmental and animal welfare concerns, many studies indicate that health issues represent the main reason for purchasing organic food, and that health attributes have become as important as sensory ones during the buying decision-making process [3,19-23].

Health issues are considered to be part of the numerous trends which have recently appeared on the food market [24] and seem to have a personal and social value [25]. Nowadays, consumers are more informed about the food they are eating and they have become more aware of the link between food and health [5]. Moreover, organic food consumers seem to have a sustainable diet concept, being less overweight compared to non-consumers [26]. Italian consumers associate organic food products with health, but they are also interested in tasty food, meaning that the sensory attributes 
are also very important [27]. Belgian consumers have mentioned health, the lack of pesticides with direct benefits to the environment, high quality and better taste among the most important reasons for consuming organic food [28]. Polish consumers consider that health and high quality are the most important characteristics of an organic food product [29]. For Danish and British consumers, the health attribute is the third main reason for purchasing organic food following product taste and freshness [30]. In addition, French consumers purchase organic products mainly for their taste, and secondly for the health benefits [31].

The health attribute represents the main reason for purchasing organic products in Sri Lanka [22], Indonesia [32], India [33], China [34] and Thailand [35] as well. In Malaysia, respondents are also influenced in purchasing organic food by such attributes as safety, health and environment, but not by the food quality, which is unexpected, even for researchers [36]. A particular case is Taiwan, where organic food represents a relatively new product. Thus, an important factor in the purchasing process is trust, which could be gained mainly from acquaintances [37]. The lack of autonomy was also observed in Pakistan, where purchasing organic products is related to the opinions of reference groups [38].

The environmental concern has no impact on purchasing organic food in Sri Lanka [22] or Turkey [3], while, in Indonesia [32], Australia [39] and Thailand [35,40], it represents an important attribute, alongside the local origin of food and food safety. A relatively low interest is shown for the environment among Czech consumers, for which the health benefits prevail [41]. Russian consumers also show a relatively low interest for the environment, while health issues and the lack of synthetic inputs are the main reasons for purchasing organic food [23]. In India, consumers appreciate organic food for its impact on health [33], quality and the environment [42].

Zander and Hamm [43] concluded that, among the ethical attributes of organic food, animal welfare is the most important one. Thus, environmental concerns and animal rights were the main reasons for purchasing organic food in Norway [44]. Lee and Yun [21] highlighted that utilitarian and hedonic attitudes are influencing consumer behavior into purchasing organic food. Another factor that favors the purchase of organic food is the consumers' concern for the use of industrial fertilizers or pesticides in conventional agriculture and its limitations in terms of sustainability. These aspects decrease the confidence in conventional food and increase the preferences for organic products [42,45-47].

Nevertheless, there are also some important barriers in purchasing organic food, such as the premium prices compared to conventional food prices $[3,20,28,29,32,33,48]$, lack of trust in product certification [49], awareness [34,50] and lack of availability [3,34,49,51], which, for Danish consumers, is no longer a problem because of governmental reforms aimed to encourage organic consumption [52]. In Iran, the main barriers in purchasing organic products are institutional ones, followed by food quality, cultural barriers and last, economic ones [53]. Even if organic food has premium prices, this can be associated to an investment in human health [54].

In United Arab Emirates, findings indicated that men are more aware of organic products than women [55]. However, research conducted in Indonesia yielded results which indicated that gender fosters different attitudes towards organic products, women being more preoccupied by health and environmental issues than men [32]. The same results were recorded in Turkey as well as in many other countries $[19,20,26]$. The existence of children within the households constitutes an important factor for purchasing organic food $[3,11,34,40]$.

Organic food consumers tend to be older and more educated [26,40,51,56]. Nevertheless, in Sweden, for example, positive attitudes towards organic products were registered among young respondents and particularly women [48]. Income is an essential variable that influences organic food consumption, as it usually has premium prices. Scholars revealed that the low-income groups have the tendency to consume unhealthy products unlike high-income groups [57]. In the case of Turkish consumers, it was observed that low-income individuals do not purchase organic food at all [3]. 


\section{Materials and Methods}

\subsection{Sample and Data Collection}

To achieve the purpose of the study, a quantitative survey was carried out during February-May 2016. The sample size was determined based on the following formula. A relative error of $2.5 \%$, and $95 \%$ confidence interval was used.

$$
n=\frac{k^{2} \times \sigma_{x}^{2}}{\Delta_{\overline{\mathrm{x}}}^{2}+\frac{k^{2} \times \sigma_{x}^{2}}{N}}=\frac{(1.96)^{2} \times 294.11}{(1.975)^{2}+\frac{(1.96)^{2} \times 294.11}{2,078,705}}=571,93 \text { persons } \cong 572 \text { persons }
$$

where $\Delta_{\mathrm{X}}$ is the absolute error, $n$ is the size of the sample, $k$ is the probability guarantee, $\sigma_{x}^{2}$ is the variance, and $N$ is the volume of the population.

A total of 650 questionnaires were distributed in the neighborhood of the supermarkets, local markets, special shops and fairs in a face to face interview in 8 cities and 15 communes in the North-West Development Region. The survey resulted in 568 usable instruments representing an $87.38 \%$ response rate. A filter question was used to identify if the respondents consume or not organic products; 540 declared that they consume organic products and the analysis was further performed based on their responses.

The survey instrument was composed of three sections. Four items were used in the first section to gather responses from the people interviewed, concerning their perceptions on what organic products are and their organic consuming habit. The second section comprised 30 items, which were used to identify the perceptions of the consumers on organic food products and the reasons for their consumption (Table 1). Each of the 30 items were measured using 5-point Likert-style scales, where 1 = strongly disagree, 2 = disagree, $3=$ neutral, $4=$ agree, and $5=$ strongly agree. Respondents, were asked to indicate how strongly they agree or disagree with each item on the scale. The third section of the survey instrument was used to design the consumers' socio-demographic profile.

\subsection{Study Methods and Data Analysis}

Descriptive statistical analysis was used to determine the socio-demographic profile of the consumers and to indicate the means and standard deviations of each of the variables used to describe respondents' perceptions about organic food products. An exploratory factor analysis using SPSS was conducted to determine the underlying dimensions among the variables.

The 30 items were factor-analyzed, using principal component analysis (PCA) with the Varimax rotation method to establish the underlying constructs. The Varimax rotation was used to maximize the differences between the components extracted and to maintain correlation within the components. The Kaiser-Meyer-Olkin (KMO) measure of sampling adequacy and Bartlett's test of Sphericity were used to determine the fitness of the data. Values of 0.6 or above from the KMO measures indicated that data are adequate for PCA [58,59]. The most common and reliable criterion is the use of eigenvalues in extracting factors. In this research, all factors with eigenvalues greater than 1 were retained because they were considered significant, and all factors with less than 1 were discarded. In addition, all the items that showed factor loading of less than 0.50 were removed from the analysis, thus yielding 25 items that were factor analyzed again. The items with communalities below 0.5 were retained, based on Child's [60] recommendation to remove any item with a communality score lower than 0.2, while Costello and Osborne [61] indicated that communalities of 0.40 to 0.70 are more common in social sciences. Cronbach's alpha reliability coefficient was computed for each factor, to estimate the reliability of each scale. All factors with a reliability coefficient above 0.6 were considered to be acceptable in this study [62-64].

Furthermore, a cluster analysis was conducted in order to isolate different groups within the sample and examine their common features. The clusters were determined by using both 
hierarchical and non-hierarchical clustering techniques. The Ward Method, with square Euclidean distance, was used to determine the preliminary number of clusters based on the motivation factors. Furthermore, K-means cluster, a non-hierarchical clustering technique, was used.

Subsequently, one-way ANOVA was employed to compare the different groups by analyzing significant difference between their means [59]. Scheffé multiple range tests were also employed to investigate any significant differences between clusters with respect to each factor. Cross-tabulation analysis using Pearson's $\chi^{2}$ statistics was performed with the demographic data to determine the profile of the respondents from each group and if there are any significant differences among them.

\section{Results}

\subsection{Consumers Attitudes Relating to Organic Food Products}

Principal factor analysis was conducted to assess the dimensionality of the 25 items. The Barlett test of Sphericity was significant (Chi-square $=4007.864, p<0.000)$. The Kaiser-Meyer-Olkin $(\mathrm{KMO})$ overall measure of sampling was 0.77 , indicating that data were suitable for the principal component analysis [58]. The exploratory factor analysis with Varimax rotation of the 25 variables resulted in a six-factor solution that explains $55.26 \%$ of the total variance. All six factors had eigenvalues greater than 1 .

Cronbach's alpha reliability coefficient was computed to evaluate the internal consistency of each component. The overall reliability of the 25 variables was 0.80 . All the factors had reliability coefficients ranging higher than 0.6 , except the sixth factor (Social), which had a reliability coefficient less than 0.6 and it was not retained for further analysis.

Table 1 presents the six underlying dimensions resulting from the principal component analysis. The first dimension was labeled as "natural and sustainable consumption", which explained $18.83 \%$ of the total variance, with a reliability coefficient of 0.81 . The relatively large proportion of the total variance might be attributed to the fact that consumers perceive organic products as being more natural, healthy and with a positive impact on three components of sustainable development.

The first factor was comprised of five attributes and had a mean of $4.34(\mathrm{SD}=0.894)$ (Table 1). This factor involved attributes that focus on the absence of the artificial ingredients and additives of the organic products, with low impact on the environment and non-genetically modified organisms.

The second factor labeled "extrinsic attributes" comprised five attributes, which explained $12.63 \%$ of the total variance with a reliability coefficient of 0.76 . This component had a mean of 3.36 (SD $=0.966$ ), being less attractive and important for consumers, compared to the first one, in terms of buying and consuming organic products and the underlying decision-making process. This factor involves attributes that focus on the packages and labels of the organic food. The most appreciated attribute from this factor is the one related to the information that the label offers to the consumers (mean $=4.01$, $\mathrm{SD}=1.164$ ), while the less important is the one related to the design of the label (mean $=2.98, \mathrm{SD}=1.404)$. Even if the consumers showed their interest in reducing the quantity of fertilizers, pesticides, artificial colors and flavors (attributes loaded into the first factor), they were less concerned about the recyclable characteristics of the packages (mean $=3.29, \mathrm{SD}=1.426$ ). This might be explained by the low level of information, low number of selective waste collection points and lack of proper waste management plans in Romania [65].

The third factor labeled "health" contained five factors, had a mean of $4.61(\mathrm{SD}=0.521)$ and a reliability coefficient of 0.67 , which explained $7.84 \%$ of the total variance. This factor loaded attributes related to nutritional characteristics, vitamin, mineral and protein content. The high content in vitamins and minerals (mean $=4.75, \mathrm{SD}=0.649$ ) seemed to be the most important attribute of this factor that influenced the consumption of organic products.

The fourth factor called "sensory appeal" had four items loaded, nice smell, pleasant texture, good taste, and regular consumption, and had a mean of $4.22(\mathrm{SD}=0.682)$. The "sensory appeal" factor explained $6.05 \%$ of the total variance and had a reliability coefficient of 0.69 . The taste of organic 
products (mean $=4.70, \mathrm{SD}=0.655$ ) had almost the same importance as the content of vitamins and minerals in the consumers' decision-making process of buying and consuming organic products.

The fifth factor, "weight concern", loaded four items, takes no time to prepare (can be consumed fresh), high content of fibers, low in fat, and low in calories, and explained $5.64 \%$ of the total variance with a reliability coefficient of 0.6 . The "weight concern" factor had a mean of 3.73 (SD $=0.857$ ), below the one registered by the factor "health", indicating that the consumers of organic products are more interested in the nutritional characteristics of the products than the effects on their weight.

Table 1. Principal component analysis on organic food product variables.

\begin{tabular}{|c|c|c|c|c|c|c|c|}
\hline Eigenvalue & Variance $\%$ & Factor & Item & Factor Loading & Communalities & Mean & SD \\
\hline \multirow{5}{*}{4.71} & \multirow{5}{*}{18.83} & \multirow{5}{*}{$\begin{array}{c}\text { Natural and } \\
\text { sustainable } \\
\text { consumption } \\
\alpha=0.81 \\
\text { Mean }=4.34 \\
\text { SD }=0.894\end{array}$} & $\begin{array}{l}\text { No artificial colors } \\
\text { and flavors }\end{array}$ & 0.803 & $* 0.659$ & 4.41 & 1.172 \\
\hline & & & $\begin{array}{l}\text { No artificial ingredients } \\
\text { (e.g., preservatives) }\end{array}$ & 0.788 & 0.661 & 4.28 & 1.260 \\
\hline & & & $\begin{array}{l}\text { No traces of pesticides } \\
\text { and fertilizers }\end{array}$ & 0.770 & 0.643 & 4.34 & 1.201 \\
\hline & & & No GMO products & 0.681 & 0.543 & 4.30 & 1.270 \\
\hline & & & Low impact on environment & 0.609 & 0.429 & 4.37 & 1.060 \\
\hline \multirow{5}{*}{3.16} & \multirow{5}{*}{12.63} & \multirow{5}{*}{$\begin{array}{c}\text { Extrinsic attributes } \\
\alpha=0.76 \\
\text { Mean }=3.36 \\
\mathrm{SD}=0.966\end{array}$} & Package is attractive & 0.721 & 0.730 & 3.14 & 1.449 \\
\hline & & & Packages are recyclable & 0.721 & 0.561 & 3.29 & 1.426 \\
\hline & & & Label is attractive & 0.693 & 0.696 & 2.98 & 1.404 \\
\hline & & & $\begin{array}{l}\text { Label offers information } \\
\text { about quality, nutritional } \\
\text { aspects }\end{array}$ & 0.653 & 0.541 & 4.01 & 1.164 \\
\hline & & & $\begin{array}{l}\text { Package offers information } \\
\text { about consume }\end{array}$ & 0.614 & 0.452 & 3.42 & 1.275 \\
\hline \multirow{5}{*}{1.96} & \multirow{5}{*}{7.84} & \multirow{5}{*}{$\begin{array}{c}\text { Health } \\
\alpha=0.67 \\
\text { Mean }=4.61 \\
\text { SD }=0.521\end{array}$} & High nutritional value & 0.722 & 0.618 & 4.34 & 1.023 \\
\hline & & & $\begin{array}{l}\text { Rich in vitamins and } \\
\text { minerals }\end{array}$ & 0.602 & 0.551 & 4.75 & 0.649 \\
\hline & & & Are healthy & 0.586 & 0.434 & 4.71 & 0.755 \\
\hline & & & Rich in proteins & 0.582 & 0.433 & 4.56 & 0.834 \\
\hline & & & Natural ingredients & 0.527 & 0.441 & 4.70 & 0.666 \\
\hline \multirow{4}{*}{1.51} & \multirow{4}{*}{6.05} & \multirow{4}{*}{$\begin{array}{c}\text { Sensory appeal } \\
\alpha=0.69 \\
\text { Mean }=4.22 \\
\mathrm{SD}=0.682\end{array}$} & Smells nice & 0.716 & 0.545 & 4.44 & 0.895 \\
\hline & & & Pleasant texture & 0.697 & 0.545 & 3.96 & 1.146 \\
\hline & & & Taste good & 0.686 & 0.584 & 4.70 & 0.655 \\
\hline & & & Regular consumed & 0.571 & 0.455 & 3.80 & 1.156 \\
\hline \multirow{4}{*}{1.44} & \multirow{4}{*}{5.64} & \multirow{4}{*}{$\begin{array}{c}\text { Weight } \\
\text { concern } \\
\alpha=0.6 \\
\text { Mean }=3.73 \\
\mathrm{SD}=0.857\end{array}$} & Takes no time to prepare & 0.730 & 0.579 & 3.46 & 1.335 \\
\hline & & & High content of fibers & 0.619 & 0.666 & 4.25 & 1.050 \\
\hline & & & Low in fat & 0.606 & 0.530 & 3.67 & 1.229 \\
\hline & & & Low in calories & 0.542 & 0.418 & 3.54 & 1.470 \\
\hline \multirow[t]{2}{*}{1.07} & \multirow[t]{2}{*}{4.27} & \multirow{2}{*}{$\begin{array}{c}\text { Social statute } \\
\alpha=0.48 \\
\text { Mean }=2.93 \\
\text { SD }=1.215\end{array}$} & Premium (luxury) products & 0.795 & 0.654 & 3.11 & 1.537 \\
\hline & & & It is fashionable & 0.503 & 0.547 & 2.76 & 1.462 \\
\hline $\begin{array}{c}\text { Total } \\
\text { variance } \\
\text { percentage }\end{array}$ & 55.26 & & & & & & \\
\hline
\end{tabular}

This might be explained by the fact that organic products are perceived as being healthy with positive effects on weight control. The sixth factor, labeled "Social", loaded two items and explained $4.27 \%$ of the total variance with a reliability coefficient of 0.48 . Even if the social component is an important pillar of sustainable development, it was decided to remove this factor from the future analysis of the data due to the low consistency of the scale.

\subsection{Attitude towards Organic Products across Clusters of Consumers}

Based on the five dimensions of the PCA, a two-step cluster analysis was employed (a Ward's hierarchical ascendant classification followed by a K-means clustering for stabilization purpose). It allowed for the identification of three clusters of organic product consumers. Multivariate statistics indicated that significant differences existed between the three clusters $(p<0.001)$ (Table 2$)$. 
The factors with the highest influence on the clustering of the consumers were "natural and sustainable consumption" and "extrinsic attributes" (Table 2). Furthermore, the clusters were labeled based on the two factors considered the most important for each of the groups (Tables 2 and 3).

Table 2. Final cluster centers.

\begin{tabular}{|c|c|c|c|c|c|}
\hline Factors & $\begin{array}{c}\text { Cluster } 1 \\
(n=66,12.22 \%)\end{array}$ & $\begin{array}{c}\text { Cluster } 2 \\
(n=285,52.78 \%)\end{array}$ & $\begin{array}{c}\text { Cluster } 3 \\
(n=189,35.0 \%)\end{array}$ & $F$ Value & Significance \\
\hline $\begin{array}{l}\text { Natural and sustainable } \\
\text { consumption }\end{array}$ & -2.095124 & 0.394237 & 0.137146 & 449.936501 & 0.000 \\
\hline Extrinsic attributes & 0.184133 & 0.524107 & -0.854620 & 183.140515 & 0.000 \\
\hline Health aspects & 0.375763 & 0.339933 & -0.643817 & 77.386549 & 0.000 \\
\hline Sensory appeal & 0.348757 & -0.016644 & -0.096690 & 5.010264 & 0.007 \\
\hline Weight concern & -0.362732 & -0.064218 & 0.223505 & 9.971582 & 0.000 \\
\hline
\end{tabular}

The ANOVA test also indicated that all five factors contributed to differentiating the three clusters $(p<0.001)$. In addition, Scheffé multiple-range tests were further employed to explore any differences between clusters with respect to each factor. The result of the Scheffé test indicated that there were statistically significant differences between clusters, except for the sensory appeal factor (Table 3).

Table 3. Results of cluster analysis for consumers' motivation.

\begin{tabular}{|c|c|c|c|c|c|c|c|}
\hline \multirow{2}{*}{ Factors } & \multirow{2}{*}{ Cluster 1} & \multirow{2}{*}{ Cluster 2} & \multirow{2}{*}{ Cluster 3} & \multirow{2}{*}{$F$ Value } & \multicolumn{3}{|c|}{ Scheffé Multiple Range Tests } \\
\hline & & & & & I-II & I-III & II-III \\
\hline $\begin{array}{l}\text { Natural and sustainable } \\
\text { consumption }\end{array}$ & 2.51 & 4.73 & 3.38 & $427.100^{* * *}$ & $* * *$ & $* * *$ & $* * *$ \\
\hline Extrinsic attributes & 3.52 & 3.85 & 2.56 & $163.994^{* * *}$ & $* *$ & $* * *$ & $* * *$ \\
\hline Health aspects & 4.64 & 4.83 & 4.28 & $83.315^{* * *}$ & $*$ & $* * *$ & $* * *$ \\
\hline Sensory appeal & 4.38 & 4.29 & 3.08 & $7.775^{* * *}$ & $\mathrm{n} / \mathrm{a}^{\mathrm{a}}$ & ** & $* *$ \\
\hline Weight concern & 3.33 & 3.86 & 3.67 & $11.597^{* * *}$ & $* * *$ & * & * \\
\hline
\end{tabular}

Cross-tabulation and Pearson's $\chi^{2}$ statistics were used to identify the profile of the organic product consumers in terms of their gender, age, education level, monthly income, types of consumed organic products and perceptions about what an organic food product is. The cross-tabulation approach allowed the researchers to identify the communalities of each group. The results indicated that the majority of the respondents were male, over 35 years old, and with secondary education (high school). Fruits, vegetables, and dairy products had the highest share in the organic food consumption, while sweets were the least consumed (Table 4). 
Table 4. Demographic profile $N=540$.

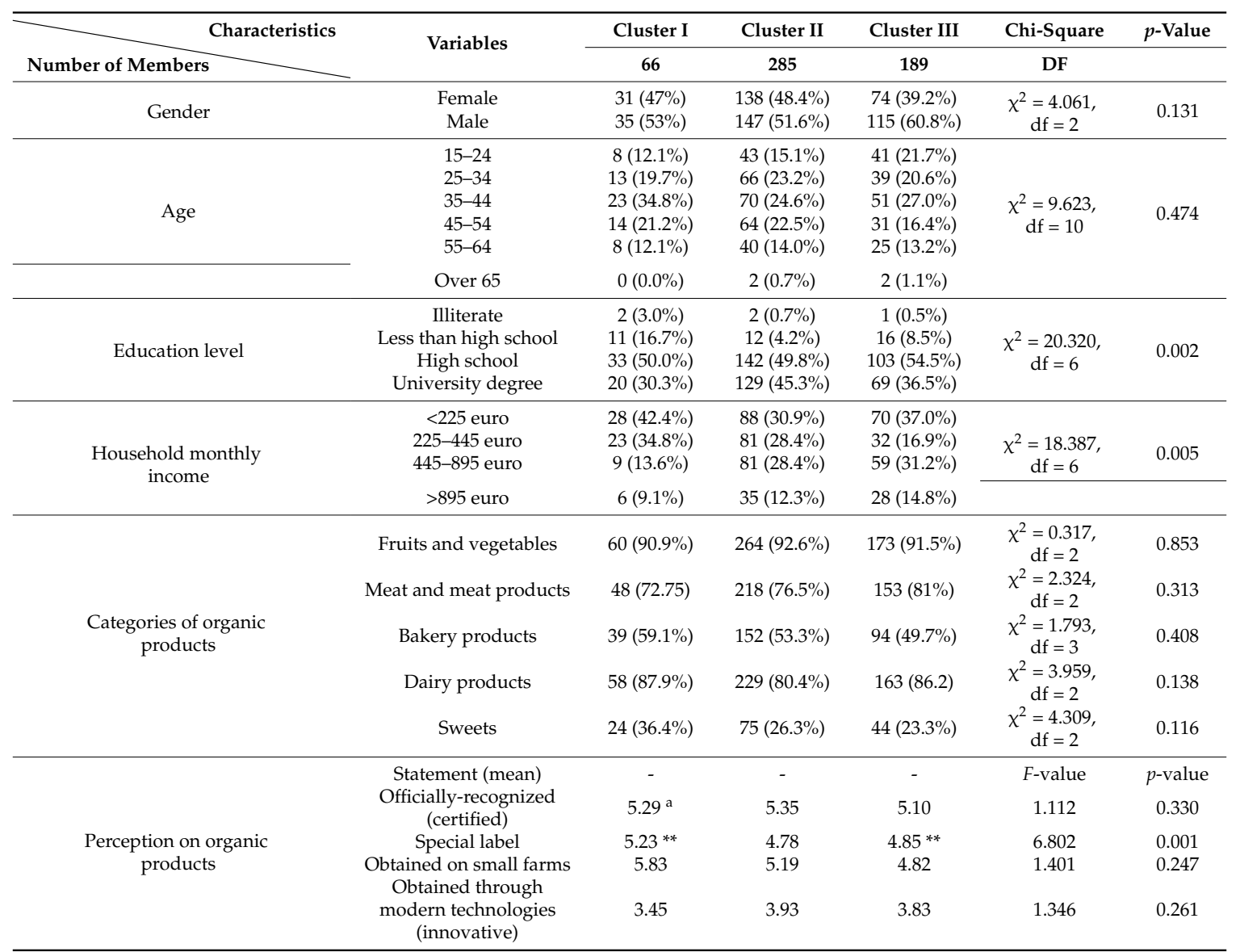

a Mean values were computed using seven-point Likert-style scale $(1=$ strongly disagree, $4=$ neutral,

7 = strongly agree); ${ }^{* *}$ indicate significantly different means using Scheffé post hoc, ${ }^{* *} p<0.01$

The clusters were subsequently named according to the two factors considered to be the most important to distinctively represent the three segments that were established (Tables 2 and 3). The results indicated that each of the three groups highly appreciate the health benefits of consuming organic products.

Cluster $1(N=66)$ : "Gourmand" was the smallest and represented $12.22 \%$ of the consumers. Cluster 1 appeared to have the highest mean scores in terms of "health aspects" and "sensory appeal". This cluster registered the lowest mean score on the "natural and sustainable consumption" factor (2.51). Therefore, it can be concluded that consumers in this group are less concerned about sustainable consumption and more preoccupied with the sensory aspects of the food and effects on their health, even if this is not necessarily related to natural products. The first cluster grouped the highest percentage of people aged $24-44$ years old $(54.5 \%)$ with the highest share of monthly household income below 225 euro.

Cluster 2 ( $N=285)$ : "Environmentally concerned" was the largest group and represented 52.78\% of the consumers. Cluster 2 had the highest mean score on "natural and sustainable consumption" (mean $=4.73$ ) and "health aspects" (mean $=4.83)$, and the lowest mean score for "extrinsic attributes" (mean $=3.85)$ and "weight concern" (mean = 3.86). The second cluster exhibited the highest share of female consumers and highest percentage of members with university degree, reinforcing the results of previous studies [32,48].

Cluster $3(N=189)$ : "Health concerned" characterized $35 \%$ of the consumers. Cluster 3 appeared to have the highest mean score on "health aspects" and "weight concern". However, this cluster had the lowest mean score on "extrinsic attributes". More than $45 \%$ of the consumers in this cluster have a 
monthly household income higher than 445 euro, and they consume less bakery and sweet organic products, compared to the other two groups.

The findings indicated that "health aspects" had the highest mean score for all three clusters, while the lowest mean score were registered for "extrinsic attributes", except Cluster 1, where the lowest mean was registered for the "weight concern" factor.

\section{Discussion}

The results indicated that the natural and sustainable consumption component of the factor analysis has a high importance in the buying decision process of the organic food products. It is believed that, alongside satisfying hunger, food encompassed additional traits that are linked to sustainable development and consumption, but also to some ethical aspects such as animal welfare, environment safety and the lack of pesticides $[19,28]$. Scholars pointed out that organic food consumers are concerned with the use and effects of pesticides and fertilizers in conventional agriculture in terms of sustainability [42,45-47]. This cannot be generalized because there were cases where these aspects had no influence on the decision of consuming organic products [3,22]. Another important factor that influences consumers' decision on consuming organic products is related to the "health aspects" factor, consumers being more informed about food quality and its effects on their health condition [5]. The importance of health aspects and the environmental concern were underlined by other findings as well $[9,11,12]$. Based on this, it can be stated that the Romanian consumers are increasingly preoccupied by the effects of their eating habits on their health and the environment.

The "extrinsic attributes" of the organic products were not considered to be the main reasons for consumers to buy organic products, but it was appreciated due to the important information on the ingredients and nutritional aspects, the factors that influence organic food consumers' buying behavior.

The largest group of consumers "Environmentally concerned" (Cluster 2) agreed that organic products are obtained with reduced quantities of fertilizers, pesticides, and artificial color; exerting a low impact on the environment; and having a high content of vitamins, minerals and natural ingredients at the same time. Organic agriculture can contribute to socio-economic and environmental sustainable development [66]. The health attribute has a high importance in the consumption decision of organic products for the members of the second cluster, reinforcing the findings of previous studies $[22,28,31]$. This group has the largest number of females, compared to the other two groups. This can be explained by the fact that females are more concerned with the nutritional aspects of the products, but they are also the family's main caretaker responsible for food purchases and are willing to pay more for premium products [54]. The concern with natural and sustainable consumption can be explained by the fact that the second group also includes the highest number of consumers with a university degree, meaning that they have more knowledge about the importance of the subject. They are also aware and agree that in order to label a product as being organic, it is important for the product to be officially recognized and certified (mean $=5.35$ ).

The second largest cluster was the "Health concerned" (Cluster 3) group of consumers, who are preoccupied with the nutritional aspects of the organic products, and their effects on the weight control with statistically significant differences from the other two clusters. This group includes the largest number of male respondents with a high school degree, and the highest household monthly income (14.8\% declared more than 895 euro per month) with statistically significant differences from the other two groups of consumers. Income has a direct impact on the consumers' eating habits, those with lower incomes tend to consume less healthy products [57] and they are not so open to try organic products, since these are considered to be premium products $[3,12,57]$. Being concerned with their weight control, compared to the other two groups of organic product consumers, the members of the third cluster seem to consume less bakery products and sweets, even if there were no statistically significant differences between the three groups of consumers. Padel and Foster [20] underlined that consumers associate organic food products primarily with fruits and vegetables, which represents, in many cases, the first experience of buying and consuming organic products. The consumers of organic products are more 
preoccupied with their weight and have a more sustainable diet [26]. Surprisingly, this group has the highest share of males, compared to the other two groups, since the topic of weight control seems to be rather a topic for females [67], but, at the same time, men reported higher levels of pre-treatment of weight control self-efficiency [68].

The findings indicated that the "Gourmand" cluster (Cluster 1) is the smallest group of consumers $(12.22 \%)$, and it represents those consumers preoccupied with the food content in vitamins and minerals, as well as the texture and taste of food, indicating that sensorial attributes are very important for these consumers $[21,22,27]$. Consumers associate organic products with health, but, at the same time, they want tasty products, because pleasure and wellbeing are important values in their life [27]. This group is less educated and has a lower monthly income compared to the other two groups; however, the members of the group are well informed about the certification (mean $=5.29$ ) and labeling of the organic products (mean $=5.23$ ). On the other hand, the age group over 35 years of age is the largest, compared to the other two groups. However, statistically significant differences were not found between clusters with respect to consumers' age or gender. This group tends to consume less fruits and vegetables compared to the other two groups. The results reinforce the idea that low income people consume less fruits and vegetables than higher income groups, with direct impact on social health inequalities [57].

The findings of the current research indicated that there are no major statistically significant differences among the three groups of organic food consumers regarding the gender and age of the members in each group. The participants in this study paid particular attention to the certification of the products when they decided to buy and consume an organic product. At the same time, they agree that organic products should be obtained on small farms, using traditional technologies. Therefore, it can be concluded that consumers see organic products and agriculture as a viable alternative for local producers and for sustainable agriculture. The fact that the most consumed organic products are fruits and vegetables reinforces the idea of sustainable agricultural development. The consumers of organic food are less attracted by processed organic products (sweets, bakery products). This might be the effect of the added value obtained during the processing of the raw materials, which is reflected in the price. Price was considered an important factor that influences the buying decision for organic products (see also $[3,19,20,28,33]$ ).

Even if the study revealed new information about Romanian organic food consumers, it has some limitations. The results are not immediately transferable to the other development regions of Romania, since there are major differences in terms of socio-demographic characteristics and economic development between the regions. The study focused on the attributes of organic products, but the consumers' willingness to pay was not analyzed during this research. Future research should also include the price as a variable to determine the Romanian organic food consumers' profile. At the same time, the barriers that limit organic food consumption should also be analyzed in order to develop sustainable market strategies.

\section{Conclusions}

Organic farming practices are becoming popular among producers and are considered an alternative for small farms. Consumers are aware of the implications the consumption of organic products has for the sustainable development of agriculture. The results of the study showed that consumers of organic products are educated people over 35 years old who are aware of the effect of their diet on their health. The increased consumer interest for organic food products was attributed to the growing demand for non-GMO, free of pesticides, high mineral and vitamin content and natural ingredients. These indicate that consumers are more aware of their health condition and sustainable diet. This aspect could be a starting point for developing market strategies to increase the consumption of organic products. Even if the factors that determine the organic food consumption were the same for all the three groups, there were statistically significant differences regarding the importance of the factors among the analyzed clusters. At the same time, the findings indicate that the respondents 
consider organic food to be obtained by traditional agricultural and processing methods instead of modern technologies. From here, it can be concluded that they are orientated to the slow food concept. The results of the study are important because they provide valuable information about consumers of organic food products in the North-West Development Region of Romania that can be used by decisions makers in their development strategies and development of short value chains, in order to support the small farms and local products.

For producers and sellers, it is important to know the profile of their consumers and their preferences to develop and adapt their products to the market based on the needs of each group of consumers. Offering the proper products, at a proper price and quality, can increase the level of satisfactions of the consumers, and thus will lead to an increase of the economic efficiency of the producers.

Author Contributions: Camelia F. Oroian, Iulia C. Muresan and Calin Safrinescu developed the concept and design of the study. Camelia F. Oroian, Calin Safrinescu and Bianca M. Bordeanu collected the data. Iulia C. Muresan and Gabriela O. Chiciudean analyzed the data. Iulia C. Muresan, Rezhen Harun and Camelia F. Oroian drafted the manuscript. Gabriela O. Chiciudean and Felix H. Arion critically revised it. All authors read and approved the final manuscript.

Conflicts of Interest: The authors declare no conflict of interest.

\section{References}

1. European Commision, Facts and Figures on Organic Agriculture in the European Union. Available online: https://ec.europa.eu/agriculture/organic/sites/orgfarming/files/docs/pages/014_en. pdf (accessed on 21 June 2017).

2. European Coomision, Agriculture and Rural Development-organic Farming. Available online: https:/ / ec.europa.eu/agriculture/organic/index_en (accessed on 21 June 2017).

3. Aygen, F.G. Attitudes and behavior of turkish consumers with respect to organic foods. Int. J. Bus. Soc. Sci. 2012, 3, 262-273.

4. Essoussi, L.H.; Zahaf, M. Exploring the decision-making process of Canadian organic food consumers: Motivations and trust issues. Qual. Mark. Res. 2009, 12, 443-459. [CrossRef]

5. Annunziata, A.; Pascale, P. Consumers' Behaviours and Attitudes toward Healthy Food Products: The case of Organic and Functional foods. In Proceedings of the 113th EAAE Seminar "A Resilient European Food Industry and Food Chain in A Challenging World", Chania, Greece, 3-6 September 2009.

6. Schleenbecker, R.; Hamm, U. Consumers' perception of organic product characteristics. A review. Appetite 2013, 71, 420-429. [CrossRef] [PubMed]

7. Ministry of Agriculture and Rural Development. Available online: http://www.madr.ro/agriculturaecologica/dinamica-operatorilor-si-a-suprafetelor-in-agricultura-ecologica.html (accessed on 22 July 2017).

8. Saracin, V.C.; Vasile, A. An Exploratory Research Regarding Romanian Organic Farming Sector. AgroLife Sci. J. 2015, 4, 119-123.

9. Bălăşescu, S. Bio agricultural product market in Romania and Europe. Bull. Transilvania Univ. Braşov 2016, 9, 265-372.

10. Sima, V. Organic Market in Romania-Actual Trends. In Recent Researches in Business Administration, Product Design and Marketing, Proceedings of the 1st International Conference on Contemporary Marketing (CMAR'13), Chania, Greece, 27-29 August 2013; WSEAS Ltd.: Belize City, Belize, 2013; pp. 37-43.

11. Dumea, A.C.; Andrei, A.G. Organic Food Consumer in Romania. Available online: http://mpra.ub.unimuenchen.de/36865/ (accessed on 22 July 2017).

12. Drăghici, M.C.; Popa, E.E.; Popa, M.E.; Miteluț, A.C. Romanian Organic Food-Study on Consumer Behaviour. J. EcoAgriTour. 2016, 12, 160-167.

13. Petrescu, A.G.; Oncioiu, I.; Petrescu, M. Perception of organic food consumption in Romania. Foods 2017, 6, 42. [CrossRef] [PubMed]

14. Dinu, T.A.; Stoian, E.; Micu, M.M.; Condei, R.; Niculae, I. Study regarding consumption of organic products in Romania. Manag. Econ. Eng. Agric. Rural Dev. 2014, 14, 113-118. 
15. Dumea, A.C. Factors influencing consumption of organic food in Romania. USV Ann. Econ. Public Admin. 2012, 12, 107-113.

16. Rojas, A.; Valley, W.; Mansfield, B.; Orrego, E.; Chapman, G.E.; Harlap, Y. Toward food system sustainability through school food system change: Think \& eatgreen at school and the making of a community-university research alliance. Sustainability 2011, 3, 763-788.

17. Papargyropoulou, E.; Lozano, R.; Steinberger, J.K.; Wright, N.; Bin Ujang, Z. The food waste hierarchy as a framework for the management of food surplus and food waste. J. Clean. Prod. 2014, 76, 106-115. [CrossRef]

18. Wiskerke, J.S.C. On places lost and places regained: Reflections on the alternative food geography and sustainable regional development. Int. Plan. Stud. 2009, 14, 369-387. [CrossRef]

19. Gil, J.M.; Gracia, A.; Sanchez, M. Market segmentation and willingness to pay for organic products in Spain. Int. Food Agribus. Man. Rev. 2000, 3, 207-226. [CrossRef]

20. Padel, S.; Foster, C. Exploring the gap between attitudes and behavior: Understanding why consumers buy or do not buy organic food. Br. Food J. 2005, 107, 606-625. [CrossRef]

21. Lee, H.J.; Yun, Z.S. Consumers' perceptions of organic food attributes and cognitive and affective attitudes as determinants of their purchase intentions toward organic food. Food Qual. Preference 2015, 39, $259-267$. [CrossRef]

22. Kapuge, K.D.L.R. Determinants of organic food buying behavior: Special reference to organic food purchase intention of Sri Lankan customers. Procedia Food Sci. 2016, 6, 303-308. [CrossRef]

23. Meixner, O.; Haas, R.; Perevoshchikova, Y.; Canavari, M. Consumer attitudes, knowledge, and behavior in the russian market for organic food. Int. J. Food Syst. Dyn. 2014, 5, 110-120.

24. Aschemann-Witzel, J.; de Hooge, I.; Amani, P.; Bech-Larsen, T.; Oostindjer, M. Consumer-related food waste: causes and potential for action. Sustainability 2015, 7, 6457-6477. [CrossRef]

25. Goetzke, B.; Nitzko, S.; Spiller, A. Consumption of organic and functional food. A matter of well-being and health? Appetite 2014, 77, 94-103. [CrossRef] [PubMed]

26. Kesse-Guyot, E.; Peneau, S.; Mejean, C.; de Edelenyi, F.S.; Galan, P.; Hercberg, S.; Lairon, D. Profiles of organic food consumers in a large sample of french adults: Results from the Nutrinet-Sante' Cohort Study. PloS ONE 2013, 8, 1-13. [CrossRef] [PubMed]

27. Zanoli, R.; Naspetti, S. Consumer motivations in the purchase of organic food: A means-end approach. Br. Food J. 2002, 104, 643-653. [CrossRef]

28. Aertsens, J.; Mondelaers, K.; Verbeke, W.; Buysse, J.; Van Huylenbroeck, G. The influence of subjective and objective knowledge on attitude, motivations and consumption of organic food. Br. Food J. 2011, 113, 1353-1378. [CrossRef]

29. Bryla, P. Organic food consumption in Poland: Motives and barriers. Appetite 2016, 105, 737-746. [CrossRef] [PubMed]

30. Wier, M.; O’Doherty Jensen, K.; Andersen, L.M.; Millock, K.; Rosenkvist, L. The character of demand in mature organic food markets: Great Britain and Denmark compared. Food Policy 2008, 33, 406-421. [CrossRef]

31. Baudry, J.; Péneau, S.; Allès, B.; Touvier, M.; Hercberg, S.; Galan, P.; Amiot, M.J.; Lairon, D.; Méjean, C.; Kesse-Guyot, E. Food choice motives when purchasing in organic and conventional consumer clusters: Focus on sustainable concerns (The NutriNet-Santé Cohort Study). Nutrients 2017, 9, 1-17. [CrossRef] [PubMed]

32. Irianto, H. Consumers' attitude and intention towards organic food purchase: An extension of theory of planned behavior in gender perspective. Int. J. Manag. Econ. Soc. Sci. 2015, 4, 17-31.

33. Yadav, R.; Pathak, G.S. Intention to purchase organic food among young consumers: Evidences from a developing nation. Appetite 2016, 96, 122-128. [CrossRef] [PubMed]

34. Biao, X.; Wang, L.; Yang, H.; Wang, Y.; Zhang, M. Consumer perceptions and attitudes of organic food products in Eastern China. Br. Food J. 2015, 117, 1105-1121.

35. Ueasangkomsate, P.; Santiteerakul, S. A study of consumers' attitudes and intention to buy organic foods for sustainability. Proc. Env. Sci. 2016, 34, 423-430. [CrossRef]

36. Wee, C.S.; Ariff, M.S.B.M.; Zakuan, N.; Tajudin, M.N.M.; Ismail, K.; Ishak, N.; Haji, L.T. Consumers Perception, Purchase Intention and Actual Purchase Behavior of Organic Food Products. Rev. Integr. Bus. Econ. Res. 2014, 3, 378-394.

37. Teng, C.; Wang, Y.M. Decisional factors driving organic food consumption: Generation of consumer purchase intentions. Br. Food J. 2015, 117, 1066-1081. [CrossRef] 
38. Al-Swidi, A.; Huque, S.M.R.; Hafeez, M.H.; Shariff, M.N.M. The role of subjective norms in theory of planned behavior in the context of organic food consumption. Br. Food J. 2014, 116, 1561-1580. [CrossRef]

39. Pearson, D.; Henryks, J.; Sultan, P.; Anisimova, T. Organic food: Exploring purchase frequency to explain consumer behaviour. J. Org. Syst. 2013, 8, 50-63.

40. Sangkumchaliang, P.; Huang, W.C. Consumers' perceptions and attitudes of organic food products in Northern Thailand. Int. Food Agribus. Manag. Rev. 2012, 15, 87-102.

41. Zagata, L. Consumers' beliefs and behavioural intentions towards organic food. Evidence from the Czech Republic. Appetite 2012, 59, 81-89. [CrossRef] [PubMed]

42. Basha, M.B.; Mason, C.; Shamsudin, M.F.; Hussain, H.I.; Salem, M.A. Consumers attitude towards organic food. Procedia Econ. Financ. 2015, 31, 444-452. [CrossRef]

43. Zander, K.; Hamm, U. Consumer preferences for additional ethical attributes of organic food. Food Qual. Preference 2010, 21, 495-503. [CrossRef]

44. Honkanen, P.; Verplanken, B.; Olsen, S.O. Ethical values and motives driving organic food choice. J. Consum. Behav. 2006, 5, 420-430. [CrossRef]

45. Saba, A.; Messina, F. Attitudes towards organic foods and risk/benefit perception associated with pesticides. Food Qual. Preference 2003, 14, 637-645. [CrossRef]

46. Crowder, D.W.; Reganold, J.P. Financial competitiveness of organic agriculture on a global scale, Proc. Natl. Acad. Sci. USA 2015, 112, 7611-7616. [CrossRef] [PubMed]

47. Lucas, M.R.; Röhrich, K.; Marreiros, C.; Fragoso, R.; Kabbert, R.; Clara, A.M.; Martins, I.; Böhm, S. Quality, Safety and Consumer Behaviour towards Organic Food. Available online: http:/ /www.cefage.uevora.pt/ pt/content/download/1562/20309/version/1/file/2008_05.pdf (accessed on 22 July 2017).

48. Magnusson, M.K.; Arvola, A.; Hursti, U.K.K.; Åberg, L.; Sjödén, P.O. Attitudes towards organic foods among Swedish consumers. Br. Food J. 2001, 103, 209-227. [CrossRef]

49. Aertsens, J.; Verbeke, W.; Mondelaers, K.; Van Huylenbroeck, G. Personal determinants of organic food consumption: A review. Br. Food J. 2009, 111, 1140-1167. [CrossRef]

50. Stolz, H.; Stolze, M.; Hamm, U.; Janssen, M.; Ruto, E. Consumer attitudes towards organic versus conventional food with specific quality attributes. J. Life Sci. 2011, 58, 67-72. [CrossRef]

51. Toit, L.; Crafford, S. Beliefs and purchasing practices of Cape Town consumers regarding organically produced food. J. Fam. Ecol. Consum. Sci. 2013, 31, 1-11.

52. Hjelmar, U. Consumers' purchase of organic food products. A matter of convenience and reflexive practices. Appetite 2011, 56, 336-344. [CrossRef] [PubMed]

53. Sadati, S.A.; Sadati, S.A.; Fami, H.S.; Del, P.T.T. Survey consumer attitude toward barriers of organic products (op) in Iran: A case study in Gorgan City. World Appl. Sci. J. 2010, 8, 1298-1303.

54. Bonti-Ankomah, S.; Yiridoe, E.K. Organic and Conventional Food: A Literature Review of the Economics of Consumer Perceptions and Preferences; Organic Agriculture Centre of Canada: Truro, NS, Canada, 2006.

55. Muhammad, S.; Fathelrahman, E.; Ullah, R.U.T. The significance of consumer's awareness about organic food products in the United Arab Emirates. Sustainability 2016, 8, 833. [CrossRef]

56. Ramesh, S.V.; Divya, M. A study on consumers' awareness attitude and satisfaction towards select organic food products with reference to Coimbatore. Int. J. Interdiscipl. Multidiscip. Stud. 2015, 2, 81-84.

57. Dibsdall, L.A.; Lambert, N.; Bobbin, R.F.; Frewer, L. J. Low-income consumers' attitudes and behaviour towards access, availability and motivation to eat fruit and vegetables. Public Health Nutr. 2002, 6, 159-168. [CrossRef] [PubMed]

58. Ding, C.; He, X. K-means Clustering via Principal Component Analysis. In Proceedings of the 21st International Conference on Machine Learning, Banff, AB, Canada, 4-8 July 2004; pp. 29-37.

59. Kaiser, H.F. Index of factorial simplicity. Psychometrika 1974, 39, 31-36. [CrossRef]

60. Child, D. The Essentials of Factor Analysis, 3rd ed.; Bloomsbury Academic: New York, NY, USA, 2006.

61. Costello, A.B.; Osborne, J.W. Best practices in exploratory factor analysis: Four recommendations for getting the most from your analysis. Pract. Assess. Res. Eval. 2005, 10, 1-9.

62. Tabachinick, B.G.; Fidell, L.S. Using Multivariate Statistics, 2nd ed.; Harper \& Row: Cambridge, UK, 1989.

63. Hair, J.F.; Anderson, R.E.; Tatham, R.L.; Black, W.C. Multivariate Data Analysis, 5th ed.; Prentice Hall: Upper Saddle River, NJ, USA, 1998.

64. Burgess, S.M.; Steenkamp, J.B.E.M. Marketing renaissance: How to research in emerging markets advances marketing science and practice. Int. J. Res. Mark. 2006, 23, 337-356. [CrossRef] 
65. Luca, F.A.; Ioan, C.A. Implementation of green marketing in the analysis of municipal waste produced in Romania, correlated with environmental policy management. Environ. Eng. Manag. J. 2014, 13, 3131-3142.

66. Kilcher, L. How organic agriculture contributes to sustainable development. J. Agric. Res. Trop. Subtrop. Suppl. 2007, 89, 31-49.

67. Neumark-Sztainer, D.; Shenvood, N.E.; French, S.A.; Jefsery, R.W. Weight control behaviors among adult men and women: Cause for concern? Obes. Res. 1999, 7, 179-188. [CrossRef] [PubMed]

68. Presnell, K.; Pells, J.; Stout, A.; Musante, G. Sex differences in the relation of weight loss self-efficacy, binge eating, and depressive symptoms to weight loss success in a residential obesity treatment program. Eat. Behav. 2008, 9, 170-180. [CrossRef] [PubMed]

(C) 2017 by the authors. Licensee MDPI, Basel, Switzerland. This article is an open access article distributed under the terms and conditions of the Creative Commons Attribution (CC BY) license (http:/ / creativecommons.org/licenses/by/4.0/). 